\title{
INTENSITY AND DURATION OF PHASES OF WOUND HEALING AFTER SURGICAL INTERVENTION IN CASES OF SPONTANEOUS PERIODONTITIS ACCOMPANIED BY VARIOUS REACTIVITY OF THE BODY
}

\section{Yurii Yarov}

The usage of the principle of optimal management, namely such effects on complicated forms, when the course of the disease is close to that of uncomplicated course of the disease is very promising in drug therapy of patients with generalized periodontitis.

The aim is to study the intensity and duration of the phases of wound healing of the mucosa after spontaneous periodontitis surgery accompanied by normo-, hyper-and hyporeactivity of the body by cytological examination of smearimprints of wound exudate.

Materials and methods: The experiments were performed on 24 adult mongrel dogs divided into three equal groups. In the first group, drugs that disrupt the reactivity of the organism were not used (normoreactivity of the organism). In the second group, the animals were simulated a condition of hyperreactivity, in the third group - the hyporeactivity of the organism. All the animals with spontaneous periodontitis underwent a patchwork surgery. In the period after surgery, cytological examination was performed on the $1^{\text {st }}, 4^{\text {th }}, 6^{\text {th }}$ and $9^{\text {th }}$ day of the experiment.

Results: It has been revealed that in cases of the normal reactivity of the organism the following periods of cellular reactions during the healing of the gums mucous membrane can be differentiated within the appropriate terms: the period of degenerative-inflammatory changes ( $1^{\text {st }}$ day), active granulocyte-macrophage reaction $\left(4^{\text {th }}\right.$ day), reparations $\left(6^{\text {th }}\right.$ day) and the period of increase of reparative processes with a decrease in the overall cellular response $\left(9^{\text {th }}\right.$ day).

Examination of smear-imprints after surgical treatment in animals with spontaneous periodontitis with hyper-and hyporeactivity of the body allowed to identify the same periods of cellular reactions during the healing of the gingival mucosa, as in cases of normoreaction with hyperreation.Tthe intensity and duration of the wound healing phases differed from those which are typical for normoreactivity of the body: granulocyte-macrophage reaction was more pronounced and lasted longer until the $6^{\text {th }}$ day, so later only on the $9^{\text {th }}$ day there were cellular signs of regeneration.

With hyporeaction, the intensity and duration of the wound healing phases differed from those which are typical for normoreactivity of the body: granulocyte reaction occurred later (only on the $6^{\text {th }}$ day) and lasted longer, signs of active regeneration appeared later on the $9^{\text {th }}$ day. Therefore, postoperative wound healing in animals with impaired body reactivity was delayed for 3-4 days.

Conclusions: Thus, direct medical correction with transforming intensity and duration of the phases of the wound process which are characteristic for impaired reactivity of the body into the phases which are typical for normoreaction is essential. It provides synchronization of necrotic and reparative processes and creates conditions for normal uncomplicated healing of periodontal soft tissues

Keywords: reactivity of the organism, spontaneous periodontitis, wound healing, cytological examination, phases of healing

How to Cite:

Yarov, Yu. (2021). Intensity and duration of phases of wound healing after surgical intervention in cases of spontaneous periodontitis accompanied by various reactivity of the body. ScienceRise: Medical Science, 2 (41), 38-42. doi: http://doi.org/10.15587/2519-4798.2021.228287

(C) The Author(s) 2021

This is an open access article under the CC BY license (http://creativecommons.org/licenses/by/4.0).

\section{Introduction}

Periodontal diseases occupy one of the leading places in the structure of dental diseases and are among the most pressing problems of dentistry in socio-economic importance [1]. This is due to their mass prevalence, significant growth of destructive forms at a young age, high recurrence rate, the consequences of tooth loss and dysfunction of the dental and maxillofacial system, the negative impact on the body as a whole $[2,3]$. In patients with concomitant somatic pathology, the prevalence of periodontal tissues reaches $67.2 \%[4,5]$.
Generalized periodontitis - a pathological process that develops in periodontal tissues due to the combined influence of various general and local exogenous and endogenous factors is the most common and severe among periodontal diseases $[6,7]$. At the same time there is a cascade of neuro-regulatory, neuro-trophic, biochemical, immunological and functional disorders, microcirculatory and metabolic disorders. Disorders of almost all types of metabolism develop: protein, lipid, carbohydrate, mineral, which eventually leads to irreversible destruction of the periodontium and periodontium bones $[8,9]$. 
In connection with the above, the search for new tools, methods and approaches to the comprehensive treatment of generalized periodontitis remains relevant $[10,11]$. General and local drug therapy has been widely used in the complex treatment of this pathology $[12,13]$. The correctness of this tactic is confirmed by numerous data from the literature on the high clinical effectiveness of the proposed and implemented drug treatment regimens for generalized periodontitis. However, the issues of clarifying the key mechanisms of development and course of the disease in each case remain relevant, in particular - the development of differentiated approaches to the choice of drugs of general and local use depending on exo- and endoparodontopathogenic factors that have the greatest impact on the pathogenesis of generalized periodontitis.

There is no doubt that the clinical features of the pathology and healing processes after treatment are due to the state of reactivity of the organism [14]. Numerous studies show that in uncomplicated and complicated forms of healing, normo-and pathoreactivity of the organism are observed, respectively. In the first case, changes in regulatory systems most fully correspond to the pathological process and thus create favorable conditions for its development. In the second - adequate changes in regulatory systems are not provided and the course of the disease is disturbed [15, 16]. Moreover, there are forms of pathoreactivity with insufficient and excessive changes in regulatory systems. When the body's response is adequate to the disease, there is a normoreactive response, which is formed by coordinated in time and level of changes in the nervous, hormonal and immune systems, which maintains homeostasis and promotes the development of adaptation. In the case of a reaction with insufficient changes in regulatory and executive systems, a hyporeactive response develops, and in the case of a reaction accompanied by excessive changes in regulatory and executive systems, a hyperreactive response is noted. The basis of the violation of the organism reactivity is the imbalance of regulatory mechanisms and the development of maladaptation syndrome [17].

According to the facts mentioned above, it is promising to use the principle of optimal management in drug therapy of patients with generalized periodontitis, for example such impact on complicated forms, when the course of the disease (condition of the damaged area, regulatory systems, timing) approaches that of uncomplicated. This requires the study of the peculiarities of the wound process in inflammatory-destructive lesions of the periodontium on the background of different reactivity of the organism.

The aim of the research was to study the intensity and duration of the phases of wound healing of the mucous membrane after surgical treatment of spontaneous periodontitis on the background of normo-, hyperand hyporeactivity of the body by cytological examination of smear-imprints of wound exudate.

\section{Materials and methods}

The experimental studies take into account the recommendations set out in the Regulation "General Ethical Principles for Animal Experimentation", approved by the First National Congress on Bioethics on September 20, 2001 (Kyiv, Ukraine) and the Regulation of the "European Convention for the Protection of Vertebrate Animals Used for Experimental and Other Scientific Purposes" (Strasbourg, 1985). Protocol of the commission on bioethics of DNMU No. 37 dated 15.10.2020.

The study was conducted on the basis of Donetsk National Medical University in 2019-2020.

The experiments were performed on 24 adult mongrel dogs weighing $8-12 \mathrm{~kg}(10.2 \pm 0.8 \mathrm{~kg})$ with a spontaneous periodontitis. The animals were divided into three groups of 8 animals. In the first group (average weight of animals $10.0 \pm 0.7 \mathrm{~kg}$ ) drugs that violate and disrupt the reactivity of the organism were not used (normoreactivity of the organism). In the second group (average weight of animals $10.2 \pm 0.8 \mathrm{~kg}$ ) animals under the scheme were administered intramuscularly an immunostimulant of lipopolysaccharide nature - pyrogenal at a dose of $10 \mu \mathrm{g} / \mathrm{kg} /$ per day. Thus, the state of hyperreactivity of the organism was modeled. Animals of the third group (average weight of animals $10.4 \pm 0.9 \mathrm{~kg}$ ) according to the same scheme enterally received immunosuppressant - azathioprine at a dose of $1.5 \mathrm{mg} / \mathrm{kg} /$ per day. Thus, the state of hyporeactivity of the organism was modeled. All animals with spontaneous periodontitis underwent careful instrumental removal of soft and hard supragingival and subgingival dental plaque, as well as medical treatment by irrigating the oral cavity with "Parodontax" rinse. Then all the animals underwent surgery on the periodontium - a patchwork surgery according to Cieszynski-Widmann-Neumann was performed.

In the period after surgery, cytological examination was performed on the $1^{\text {st }}, 2^{\text {nd }}, 6^{\text {th }}$ and $9^{\text {th }}$ day of the experiment. The nature of the phases of the wound process was determined by cytological examination by light microscopy. The method of smears, proposed by M. P. Pokrovskyi and M.S. Makarov was used [18]. Two - three prints from the same area of the oral mucosa were successively made. For a more accurate idea of the dynamics of the process, the cell composition was expressed as a percentage, counting from 100 to 300 cells from the smear-imprints of the wound in different places of the specimen. In the study of cytological drugs the types of different cellular elements were determined, taking into account their number and condition (the degree of dystrophic and degenerative changes). The dynamics of the ratio of formed blood elements and cellular tissue elements was evaluated. In addition, during the smears' analysis the presence of microbial flora was recorded and the degree of phagocytosis of microbes by neutrophils was assessed.

The preparations were stained with hematoxylineosin and examined under a microscope at a magnification of 150 .

Statistical processing of the obtained digital data was performed using the computer program Statistica 8.0 (STA862D175437Q). For each sample set of observations $(n)$, the arithmetic mean $(M)$, the standard error of the mean $(S E)$, the standard deviation $(S D)$, and the $95 \%$ confidence interval of the true mean were calculated using the Student's t-test. The level of significance of differences in the average values of the indicator in independent samples $(p)$ by the distribution function of the 
Student's t-test was calculated. At $\mathrm{p}<0.05$ the difference was assumed to be significant.

\section{Results}

Cytological examination of smears-imprints of wound exudate from the mucous membrane of the gums controlled the process of wound healing after surgical treatment of animals with spontaneous periodontitis on the background of normoreactivity of the body (Table 1). As can be seen from this table, on the $1^{\text {st }}$ day there was a degenerative-inflammatory reaction, which was characterized by the content in the drug of a large number of fresh and lysed erythrocytes, a small number (2-3-5 in the field of view) of leukocytes, in $82 \%$ of cases with destruction. Single lymphocytes, polyblasts, and macrophages were found in the smears. Phagocytosis was weak. This is a period of degenerative-inflammatory changes in the wound. On the $4^{\text {th }}$ day, signs of active granulocyte reaction were detected. In the cytogram, the number of erythrocytes decreased to 20-40 in the field of view, the number of leukocytes with pronounced dystrophic changes increased (30-40 in the field of view). This period is an active granulocyte-macrophage reaction.

Table 1

The results of cytological examination of smears - imprints of the wound of the mucous membrane in normo- (1),

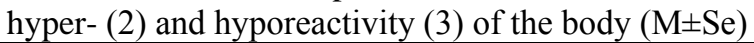

\begin{tabular}{|c|c|c|c|c|c|c|c|c|c|}
\hline \multirow{3}{*}{ Cellular elements } & \multicolumn{9}{|c|}{ Terms of observation } \\
\hline & \multicolumn{3}{|c|}{ Day 1} & \multicolumn{3}{|c|}{ Day 4} & \multicolumn{3}{|c|}{ Day 6} \\
\hline & 1 & 2 & 3 & 1 & 2 & 3 & 1 & 2 & 3 \\
\hline $\begin{array}{l}\text { The number of all } \\
\text { leukocytes in sight }\end{array}$ & $4.0 \pm 1.0$ & $8.0 \pm 2.0$ & $10.0 \pm 2.0$ & $35.0 \pm 5.0$ & $15.0 \pm 5.0$ & $45.0 \pm 5.0$ & $15.0 \pm 5.0$ & $25.0 \pm 5.0$ & $35.0 \pm 5.0$ \\
\hline $\begin{array}{l}\text { Percentage of destro- } \\
\text { yed leukocytes }(\%)\end{array}$ & $82.0 \pm 5.0$ & $94.0 \pm 6.0$ & $96.0 \pm 7.0$ & $62.0 \pm 4.0$ & $80.0 \pm 5.0$ & $92.0 \pm 6.0$ & $48.0 \pm 3.0$ & $69.0 \pm 4.0$ & $81.0 \pm 5.0$ \\
\hline $\begin{array}{l}\text { Cell composition } \\
\text { (\%):Neutrophils }\end{array}$ & $86.0 \pm 5.0$ & $76.0 \pm 4.0$ & $93.0 \pm 7.0$ & $90.0 \pm 6.0$ & $88.0 \pm 6.0$ & $97.0 \pm 7.0$ & $54.0 \pm 4.0$ & $90.0 \pm 6.0$ & $91.0 \pm 6.0$ \\
\hline Eosinophils & - & $0.30 \pm 0.04$ & $1.0 \pm 0.2$ & $0.30 \pm 0.04$ & $0.10 \pm 0.02$ & $0.80 \pm 0.06$ & $0.20 \pm 0.01$ & $0.30 \pm 0.04$ & $0.80 \pm 0.06$ \\
\hline Lymphocytes & $1.8 \pm 0.3$ & $0.80 \pm 0.06$ & $0.60 \pm 0.04$ & $2.2 \pm 0.04$ & $1.0 \pm 0.2$ & $0.90 \pm 0,08$ & $5.2 \pm 0.9$ & $1.9 \pm 0.3$ & $1.2 \pm 0.2$ \\
\hline Monocytes & - & - & - & $0.10 \pm 0.01$ & - & - & $0.10 \pm 0.01$ & $0.10 \pm 0.01$ & $0.10 \pm 0.01$ \\
\hline Polyblasts & $4.6 \pm 0.6$ & $1.4 \pm 0.2$ & $1.0 \pm 0.2$ & $5.4 \pm 0.9$ & $2.9 \pm 0.4$ & $2.3 \pm 0.4$ & $2.2 \pm 0.4$ & $4.2 \pm 0.6$ & $4.4 \pm 0.6$ \\
\hline Macrophages & $2.4 \pm 0.4$ & $0.20 \pm 0.01$ & $0.40 \pm 0.04$ & $4.2 \pm 0.6$ & $2.2 \pm 0.4$ & $2.8 \pm 0.4$ & $8.6 \pm 1.2$ & $3.2 \pm 0.5$ & $3.3 \pm 0.5$ \\
\hline Fibroblasts & - & - & - & $0.20 \pm 0.01$ & - & - & $10.4 \pm 1.2$ & $0.10 \pm 0.01$ & - \\
\hline
\end{tabular}

Leukocytes were represented mainly by neutrophils $(90 \%)$. There were polyblasts, lymphocytes, monocytes, macrophages, eosinophils. Single fibroblasts appeared. Phagocytosis was extra- and intracellular, active. On the $6^{\text {th }}$ day, the smears showed cellular signs of reparative processes, namely: a marked increase in the number of polyblasts, fibroblasts. During this period, against the background of a small number of erythrocytes, the number of neutrophils decreased 1.66 times compared with the $4^{\text {th }}$ day. Phagocytosis was moderate. This period is characterized by the appearance of cellular signs of repair. On the $9^{\text {th }}$ day, cytological examination of smears showed a decrease in the overall cellular response - a small number of destroyed neutrophils was detected, there were single polyblasts, fibroblasts. A large number of fibrous formations appeared. Phagocytosis was extraand intracellular, active. This is a period of increasing reparative processes with a decrease in the overall cellular response. Dynamic study of the cytological pattern of smears from the mucous membrane of the gums after surgery in animals with spontaneous periodontitis on the background of increased reactivity of the body revealed the same phases of the wound process as in normoreaction: the period of initial degenerative changes, increase in inflammation with active granulocyte-macrophage reaction and increase in reparative processes. The differences relate mainly to the severity and timing of the phases of the cellular response (table 1 ). On the $1^{\text {st }}$ day of observation, a necrotic type of cytogram was registered. Against the background of a large number of fresh and lysed erythrocytes, a large amount of detritus, leukocytes in large amount (8-10-12 in the field of view) were detected. Cells were destroyed, the microflora was extracellular. On the $4^{\text {th }}$ day, the number of erythrocytes in the smears decreased, but their number exceeded the corresponding values during normoreaction. The number of degeneratively altered neutrophils also exceeded that amount of normoreactivity. Phagocytosis was reduced. At a later date $\left(6^{\text {th }}\right.$ day) almost the same amount of neutrophils as at previous days was detected. There also was determined a slight increase in the number of lymphocytes, polyblasts, macrophages. There were eosinophils in greater numbers than in normoreaction. Single polyblasts were registered, there were no fibroblasts in the field of view. This suggests that granulocyte and mononuclear reactions were significantly pronounced and prolonged for 2-3 days compared with normoreactivity. Therefore, signs of regeneration in the wound appear only on the $9^{\text {th }}$ day. During this period, a small number of erythrocytes and neutrophils were detected in the smearsimprints of wound exudate. The number of polyblasts, fibroblasts increased, which indicated the beginning of healing.

Dynamic study of the cytological pattern of smears from the mucous membrane of the gums after surgery in animals with spontaneous periodontitis on the background of reduced reactivity of the body revealed the same phases of the wound process as in normoreaction: period of initial degenerative changes, increased inflammation with active granulofacitary re- 
action and the growth of reparative processes. The differences were mainly related to the timing of the cellular response phases development (Table 1). On the $1^{\text {st }}$ day of observation, a necrotic type of cytogram was registered. Against the background of a large number of fresh and lysed erythrocytes, detritus was identified. A number of leukocytes reached up to 6-8-10 in the area of view ( $76 \%$ of them were neutrophils). The cells were destroyed, the microflora was extracellular. On the $4^{\text {th }}$ day, the number of erythrocytes in the smears decreased. The number of degeneratively altered neutrophils and lymphoid polyblasts slightly increased. Phagocytosis was reduced, indicating a low protective response of the body. At a later date ( $6^{\text {th }}$ day) almost the same number of neutrophils was determined; an increase in the number of lymphocytes, polyblasts, macrophages was noticed. In isolated cases, eosinophils, monocytes, fibroblasts were encountered. The microflora was extracellularly and intracellularly in the stage of distorted phagocytosis (whole microorganisms were among the fragments of neutrophils). This suggests that granulocyte and mononuclear reactions occur 2-3 days later compared with normoreactivity. This reaction lasted longer and the signs of active regeneration in the wound were determined only on the $9^{\text {th }}$ day. During this period, a small number of erythrocytes and neutrophils were registered in the smears-imprints of the wound exudate. The number of polyblasts, fibroblasts increased, which indicated the beginning of healing.

\section{Discussion of research results}

It was found that within the normoreactivity of the organism it can be distinguished the following periods of cellular reactions during the healing of the gingival mucosa with the appropriate terms: the period of degenerative-inflammatory changes $\left(1^{\text {st }}\right.$ day), active granulocytemacrophage reaction ( $4^{\text {th }}$ day) and the appearance of cellular signs of repair ( $6^{\text {th }}$ day), and the period of increase of reparative processes with a decrease in the overall cellular response $\left(9^{\text {th }}\right.$ day). These terms of the wound healing phases form a normoreactive response to damage with synchronization of necrotic and reparative processes, ultimately, provides conditions for normal uncomplicated healing of periodontal soft tissues.

Examination of smears after surgical treatment in animals with spontaneous periodontitis with hyperreactivity of the body allowed identification of the same periods of cellular reactions during the healing of the gingival mucosa, as in normoreaction. However, the intensity and duration of the wound healing phases differed from those in normoreactivity of the body: granulocytemacrophage reaction was more pronounced and lasted longer until the $6^{\text {th }}$ day, so later only on the $9^{\text {th }}$ day there were cellular signs of regeneration. Therefore, postoperative wound healing in animals with increased reactivity of the body was delayed for 3-4 days; it was complicated.

Examination of smears after surgical treatment in animals with spontaneous periodontitis with hyporeactivity of the body allowed identification of the same periods of cellular reactions during the healing of the gingival mucosa, as in normo- and hyperreaction. However, the intensity and duration of the wound healing phases differed from those in the body's normoreactivi- ty: the granulocyte reaction occurred later (only on the $6^{\text {th }}$ day) and lasted longer, signs of active regeneration appeared later on the $9^{\text {th }}$ day. Therefore, postoperative wound healing in animals with reduced reactivity was delayed for 3-4 days. It was complicated, as in hyperreactivity.

Study limitations. We did not perform a biopsy of the mucous membrane of the gums and, accordingly, it is not possible to describe the morphology of the phases of wound healing in spontaneous periodontitis, so we do not have the opportunity for a deeper and more detailed analysis. But the cytological examination by the method of smears-imprints allows non-invasive monitoring of the intensity and duration of cellular reactions during wound healing. The quantitative analysis of the cell composition at different times of wound healing is the confirmation of the obtained results.

Prospects for further research. The generalization of the results of smears-imprints cytological examination after surgical treatment in animals with spontaneous periodontitis with normo-, hyper- and hyporeactivity of the organism revealed different intensity and duration of phases of the healing process depending on the state of reactivity of the organism to such at normoreaction of an organism. This is considered by us as a condition for optimizing the healing process after surgery on periodontal tissues, which has become the subject of further research.

\section{Conclusions}

1. At normoreactivity of an organism the following phases of healing of a gums mucous membrane with the corresponding terms are allocated: degenerativeinflammatory changes $\left(1^{\mathrm{s}} \mathrm{t}\right.$ day), active granulocytemacrophage reaction $\left(4^{\text {th }}\right.$ day), appearance of cellular signs of repair $\left(6^{\text {th }}\right.$ day $)$ and the period of reparative processes increase with a decrease in the overall cellular response $\left(9^{\text {th }}\right.$ day $)$.

2. The timing and intensity of the phases of wound healing during normoreactivity of the body are a consequence of the synchronization of necrotic and reparative processes. They also create conditions for normal uncomplicated healing of soft periodontal tissues.

3 . The same periods of cellular reactions during the healing of the gingival mucosa as in normoreaction were selected during hyper- and hyporeactivity of the organism in animals with a spontaneous periodontitis.

4. The intensity and duration of the phases of wound healing in hyper- and hyporeaction differed from those in normoreactivity of the organism.

5. Post-surgery wound healing in animals with altered (hyper- and hypo) reactivity of the body was delayed for 3-4 days compared with that of normoreaction; that is, it was complicated.

Thus, it is advisable to develop targeted drug correction, which will allow the impaired reactivity of the body to bring the intensity and duration of periods of cellular reactions in wound healing to those such as during normoreaction.

\section{Conflict of interests}

The authors declare that they have no conflicts of interest. 


\section{References}

1. Danylevskyi, M. F., Borysenko, A. V., Antonenko, M. Yu. et. al.; Borysenko, A. V. (Ed.) (2018). Terapevtychna stomatolohiia. Vol. 3: Zakhvoriuvannia parodonta. Kyiv: Medytsyna, 624.

2. Alkan, A., Cakmak, O., Yilmaz, S., Cebi, T., Gurgan, C. (2015). Relationship between psychological factors and oral health status and behaviors. Oral Health Prev Dent, 13 (4), 331-339. doi: http://doi.org/10.3290/j.ohpd.a32679

3. Slots, J. (2017). Periodontitis: facts, fallacies and the future. Periodontology 2000, 75 (1), 7-23. doi: http://doi.org/10.1111/prd.12221

4. Anwar, N., Zaman, N., Nimmi, N., Chowdhury, T. A., Khan, M. N. (2016). Factors Associated with Periodontal Disease in Pregnant Diabetic Women. Mymensingh Medical Journal, 25 (2), 289-295.

5. Petrushanko, T. A., Chereda, V. V., Loban, G. A. (2017). The relationship between colonization resistance of the oral cavity and individual-typological characteristics of personality: dental aspects. Wiadomosci Lekarskie, LXX (4), $754-757$.

6. Repetska, O., Rozhko, M., Skripnik, N., Ilnitska, O. (2020). Prevalence and intensity of periodontal tissue diseases in young persons against primary hypothyroidism. Suchasna stomatolohiya, 1, 46-48. doi: http://doi.org/10.33295/1992-576x-2020-1-46

7. Markovska, I. V., Sokolova, I. I. (2019). Dynamika stomatolohichnoho statusu patsiientiv, yaki piddaiutsia vplyvu neionizuiuchoho nyzkochastotnoho elektromahnitnoho vyprominiuvannia promyslovoi chastoty (70kHts). East Scientific Journal, $9(2), 16-19$.

8. Sommakia, S., Baker, O. (2016). Regulation of inflammation by lipid mediators in oral diseases. Oral Diseases, 23 (5), 576-597. doi: http://doi.org/10.1111/odi.12544

9. Denga, O. V., Pindus, T. A., Bubnov, V. V. (2018). Soderzhanie interleikinov IL-8 i IL-12 v sliune patsientov s khronicheskim generalizovanym parodontitom i metabolicheskim sindromom. Modern Science, 1, 121-126.

10. Chukkapalli, S. S., Easwaran, M., Rivera-Kweh, M. F., Velsko, I. M., Ambadapadi, S., Dai, J. (2017). Sequential colonization of periodontal pathogens in induction of periodontal disease and atherosclerosis in LDLRnull mice. Pathogens and Disease, 75 (1), 1-10. doi: http://doi.org/10.1093/femspd/ftx003

11. Yu, Y.-H., Chasman, D. I., Buring, J. E., Rose, L., Ridker, P. M. (2015). Cardiovascular risks associated with incident and prevalent periodontal disease. Journal of Clinical Periodontology, 42 (1), 21-28. doi: http://doi.org/10.1111/jcpe.12335

12. Popovich, I. Iu., Petrushanko, T. O. (2018). Local medication of patient's mouth cavity after the dental implantation. Suchasna stomatolohiya, 4, 46-48.

13. Sokolova, I. O., Skydan, K. V., Skydan, M. I., Levitskiy, A. P., Slynko, Y. A. (2019). Pathogenetic mechanisms of experimental gingivitis progression under the influence of lipopolysaccharide. World of Medicine and Biology, 15 (67), $187-190$. doi: http://doi.org/10.26724/2079-8334-2019-1-67-187

14. De Iuliis, V., Ursi, S., Di Tommaso, L. M., Caruso, M., Marino, A. (2016). Comparative molecular analysis of bacterial species associated with periodontal disease. Journal of Biological Regulators and Homeostatic Agents, 30 (4), 1209-1215.

15. Foey, A. D., Habil, N., Al-Shaghdali, K., Crean, S. (2017). Porphyromonas gingivalis-stimulated macrophage subsets exhibit differential induction and responsiveness to interleukin-10. Archives of Oral Biology, 73, 282-288. doi: http://doi.org/10.1016/j.archoralbio.2016.10.029

16. Kimak, H. B., Melnychuk, H. M., Rozhko, M. M., Kononenko, Yu. H., Shovkova, N. I. (2013). Sposib likuvannia heneralizovanoho parodontytu. Klinichna stomatolohiia, 3, 63.

17. Saveleva, N. M. (2017). Results of integrated treatment of generalized parodontitis I-II degree of chronicity of chronic current on the background of toxocarosis. Bulletin of Scientific Research, 1, 112-116. doi: http://doi.org/10.11603/24158798.2017.1.7534

18. Sokrut, V. N. (1992). Formy reaktivnosti organizma i zazhivlenie infarkta miokarda. Donetsk: Donetskii gos.med. in-t., 467.

Received date 01.12.2020

Accepted date 24.12.2020

Published date 31.03.2021

Yarov Yuriy, Doctor of Philosophy, Associate Professor of the Department of Dentistry No. 2, Donetsk National Medical University, Privokzalna str., 27, Liman, Donetsk region, Ukraine, 84404 